\title{
PENEGAKAN HUKUM OLEH POLISI DALAM TINDAK PIDANA KEKERASAN OLEH ANAK YANG BERBASIS KEADILAN DI KABUPATEN SIAK INDRAPURA
}

\author{
Hari Budiyanto \\ Magister Ilmu Hukum Universitas Diponegoro \\ harbud38@yahoo.com \\ No. Telepon 08117042006
}

\begin{abstract}
ABSTRAK
Penanganan kenakalan anak yang tidak tepat serta sikap keragu-raguan aparat penegak hukum dalam menangani kriminalitas yang dilakukan oleh anak, secara langsung maupun tidak langsung telah mendorong suatu penyimpangan sosial. Aparat kepolisian terkesan kehilangan konsep dalam menangani masalah kriminalitas dengan kekerasan yang dilakukan oleh anak. Oleh karena itu Polri sebagai pengayom, pelindung, dan pelayan masyarakat serta sebagai aparat penegak hukum dituntut untuk cepat tanggap dalam menjawab image negatif tersebut. Masalah yang diteliti dalam penelitian ini adalah penegakan hukum oleh polisi dalam tindak pidana kekerasan anak dan bagaimana implikasi terhadap perwujudan keadilan di Kabupaten Siak Indrapura, faktor penghambat dalam penegakan hukum oleh polisi dalam tindak pidana kekerasan oleh anak sehingga perwujudan keadilan belum tercapai di Kabupaten Siak Indrapura serta kontruksi penegakan hukum oleh polisi terhadap tindak pidana kekerasan oleh anak sehingga perwujudan keadilan dapat tercapai di Kabupaten Siak Indrapura. Metode yang digunakan dalam penelitian ini adalah dengan pendekatan sociolegal research yang bersumber dari pengumpulan data yang diperoleh dari data primer dan data sekunder, kemudian dianalisis dengan metode analisis kualitatif. Hasil penelitian ini pada akhirnya memberikan jawaban bahwa penegakan hukum oleh polisi dalam tindak pidana kekerasan anak terhadap perwujudan keadilan di Kabupaten Siak Indrapura adalah masih menggunakan kekerasan untuk mendapatkan pengakuan atau keterangan dari anak pelaku tindak pidana kekersan dalam penyidikan. Bentuk kekerasan yang dilakukan oleh penyidik adala kekerasan fisik, psikis, maupun hukum. Faktor penghambat dalam penegakan hukum oleh polisi dalam tindak pidana kekerasan oleh anak sehingga perwujudan keadilan belum tercapai dikarenakan kurangnya pendanaan untuk mendukung pelaksanaan atau kegiatan yang mendukung pengembangan Kota Layak Anak (KLA) di Kabupaten Siak Indrapura, selain itu lambannya pencatatan kasus kekerasan oleh anak dikarenakan minimnya tenaga kerja (Sumber Daya Manusia). Selain itu kontruksi penegakan hukum oleh polisi terhadap tindak pidana kekerasan oleh anak adalah dengan membangun atau menciptakan polisi yang profesional yang harus dimulai pada taraf seleksi dan pendidikan, seingga kepolisian memiliki standar keahlian dan standar etika yang tinggi, sehingga dapat tercapai penegakan hukum yang kontruktif dalam penegakan hukum terhadap anak pelaku tindak pidana kekerasan. Saran dari penelitian ini adalah polisian Kabupaten Siak Indrapura sedianya memiliki unit khusus yang benar-benar fokus dan secara rutin melakukan penyuluhan dan sosialisasi kepada masyarakat terkait tindak pidana kekerasan yang dilakukan oleh anak.
\end{abstract}

Kata kunci: Penegakan Hukum, Polisi, Tindak Pidana, Kekerasan, Anak dan Keadilan. 


\begin{abstract}
The inappropriate handling of juvenile delinquency and the hesitancy of law enforcement officers in dealing with crimes committed by children, directly or indirectly, have led to social aberrations. Police officers seem to lose the concept of dealing with violent crimes committed by children. Therefore, Police as guardian, protector, and public servant as well as law enforcement officers are required to quickly respond in response to the negative image. The problem studied in this research is law enforcement by police in violation of child abuse and how implication to the realization of justice in Siak Indrapura Regency, obstacle factor in law enforcement by police in violent crime by child so that the realization of justice has not been reached in Siak Indrapura Regency and the construction of law enforcement by the police against violent acts by children so that the realization of justice can be achieved in Siak Indrapura Regency. The method used in this research is with sociolegal research approach that comes from collecting data obtained from primary data and secondary data, then analyzed by qualitative analysis method. The results of this study ultimately provide an answer that law enforcement by the police in the crime of child abuse and how the implication of the realization of justice in Siak Indrapura Regency is still using violence to get the acknowledgment or information from the child offender of the crime in the investigation. The forms of violence committed by investigators are physical, psychological, or legal. Inhibiting factors in law enforcement by the police in violent acts by children so that the realization of justice has not been achieved in Siak Indrapura Regency due to lack of funding to support the implementation or activities that support the development of Decent City Children (KLA) in Siak Indrapura Regency, besides the slow recording of cases of violence which occurs in children due to the lack of manpower (Human Resources). In addition, the construction of law enforcement by the police against violent crime by children is to build or create a professional police that must be started at the stage of selection and education, so that the police have high standards of ethics and expertise, so that it can be achieved law enforcement in the enforcement of the enforcement law against child perpetrators of violent crime. Suggestion from this research is polisian of Regency of Siak Indrapura should have special unit that really focus and routinely doing counseling and socialization to society related to violent crime committed by child.
\end{abstract}

Key words: Law Enforcement, Police, Crime, Violence, Children and Justice.

\title{
A. Pendahuluan
}

\section{Latar Belakang}

Keberadaan Polisi akan sangat dirasakan oleh masyarakat apabila dalam pelaksanaan tugasnya dapat memberikan dampak positif untuk memenuhi keinginan masyarakat. Dalam hal ini yang diinginkan oleh masyarakat yaitu agar Polri dapat memberikan rasa aman, masyarakat merasa terlindungi baik secara moril yaitu perasaan tenteram akan terjaminnya keselamatan jiwa individu baik di lingkungan tempat tinggal, lingkungan kerja, dan perjalanannya maupun secara materiil berupa perlindungan harta benda dan tempat tinggal. Sebetulnya upaya untuk mengupas penyebab tindak kriminal yang dilakukan secara sadis dan brutal oleh anak sekolah pun telah dibahas oleh berbagai pihak yang peduli terhadap anak muda ini. Sejumlah pakar dari berbagai profesi dan kalangan telah melakukan analisa dan mengemukakan pandangan-pandangannya terhadap berbagai tindak penyimpangan yang dilakukan oleh anak-anak pelajar sekolah yang menurutnya telah mengalami suatu pergeseran yang sudah sangat membahayakan, dan mengganggu ketentraman 
kehidupan masyarakat termasuk dalam hal ini yang ada di Kabupaten Siak Indrapura.

Sebagai contoh peristiwa yang terjadi Kabupaten Siak Indrapura, sekelompok anak/pelajar yang berjumlah sekitar 30 orang, membajak truk dan merampok muatan truk tersebut. Dalam kejadian tersebut seorang kenek supir dibacok dan sebagian yang lainnya kehilangan sejumlah uang dan barang berharga lainnya. Dengan bantuan warga setempat, polisi berhasil menangkap 11 orang pelakunya. Polisi juga berhasil menemukan sebuah celurit bernoda darah, selain gunting, parang, dan keris. Para pelajar yang tertangkap tersebut berasal dari sekolah-sekolah yang ada di Kabupaten Siak Indrapura. Tindakan-tindakan seperti itu merupakan tindakan yang tidak sepatutnya dilakukan oleh pelajar. Anak/pelajar sekolah adalah termasuk kelompok usia remaja, merupakan kelompok usia yang masih labil didalam menghadapi masalah yang harus mereka atasi. Dalam kondisi usia seperti ini, maka para pelajar cenderung mengedepankan sikap emosional dan tindakan agresif. Pada tahap ini adalah tahap dimana mereka sedang mencari jati dirinya masing- masing. Mereka berusaha agar diakui keberadaannya oleh pihak lain. Mereka mencoba mengidentifikasikan dirinya sebagai remaja yang berbeda di lingkungan sekitarnya, di sekolahnya, di jalan, bahkan dimasyarakat. Hal ini dilakukan dalam rangka mempromosikan diri mereka sendiri, suatu saat mereka bertemu dengan rekan-rekan yang bernasib sama, dengan sendirinya mereka akan membentuk suatu kelompok tertentu. Dilihat dari kaca mata pelajar, maka mereka menganggap bahwa tindakan yang telah mereka lakukan hanyalah suatu manisfestasi simbolik dari penyaluran aspirasi mereka sebagai konsekuensi dari perlakuan yang dirasakan tidak adil terhadapnya.

Bertolak belakang dengan hal tersebut diatas, pada dasarnya anak adalah generasi penerus bangsa dan penerus pembangunan, yaitu generasi yang dipersiapkan sebagai subjek pelaksana pembangunan yang bekelanjutan dan pemegang kendali masa depan suatu negara, tidak terkecuali Indonesia. Perlindungan anak Indonesia berarti melindungi potensi sumber daya insani dan membangun manusia Indonesia seutuhnya, menuju masyarakat yang adil dan makmur, material spiritual berdasarkan Pancasila dan UUD 1945.

Selan itu Undang-Undang Nomor 11 Tahun 2012 tentang Sistem Peradilan Anak yang kesemuanya mengemukakan prinsip-prinsip umum perlindungan anak, yaitu non diskriminasi, kepentingan terbaik bagi anak, kelangsungan hidup dan tumbuh kembang, dan menghargai partisipasi anak. Anak sebagai bagian dari generasi muda merupakan penerus cita-cita perjuangan bangsa dan merupakan sumber daya manusia bagi pembangunan nasional kedepan. Oleh karena itu diperlukan pembinaan secara terus menerus demi kelangsungan hidup, pertumbuhan dan perkembangan fisik, mental dan sosial serta perlindungan dari segala kemungkinan yang membahayakan atau merusak masa depan anak.

Selanjutnya perlindungan terhadap anak pada suatu masyarakat bangsa, merupakan tolak ukur peradaban bangsa tersebut, karenanya wajib diusahakan sesuai dengan kemampuan pemerintah. Kegiatan perlindungan anak merupakan suatu tindakan hukum yang berakibat hukum. Upaya-upaya perlindungan anak harus telah dimulai sedini mungkin, agar kelak anak dapat berpartisipai secara optimal bagi pembangunan bangsa dan negara. Anak berhak atas perlindungan- 
perlindungan lingkungan hidup yang dapat membahayakan atau menghambat pertumbuhan dan perkembangan dengan wajar.

\section{Kerangka Teori}

Secara umum pengertian teori adalah suatu sistem yang tersusun oleh berbagai abstraksi yang berinterkoneksi satu sama lain atau berbagai ide yang memandatkan dan mengorganisasi pengetahuan tentang dunia. Ia adalah sarana yang ringkas untuk berfikir tentang dunia dan bagaimana bekerja. kerangka teori adalah penentuan tujuan dan arah penelitian dalam memilih konsep-konsep yang tepat guna pembentukan hipotesa-hipotesanya teori oleh kebanyakan ahli dianggap sebagai sarana yang memberikan rangkuman bagaimana memahami suatu masalah dalam setiap bidang ilmu pengetahuan. Fungsi teori dalam penelitian ini adalah untuk memberikan arahan atau petunjuk dan meramalkan serta menjelaskan gejala yang diamati. Untuk mendukung pemahaman dalam menjelaskan permasalahan pada penelitian ini, maka teori yang digunakan oleh penulis yaitu: pertama, teori bekerjanya hukum; kedua, teori triadism law.

\section{Penelitian Sebelumnya}

Penelitian sebelumnya dalam tesis ini adalah Galih Martino dari Universitas Muhammadiyah Surakarta, pada tesis milik saudara Galih Martino menjelaskan tentang proses penyelesaian tindak pidana kekerasan yang dilakukan oleh pelajar dan upaya penaggulangannya di wilayah hukum polres klaten adalah dengan menempuh jalur non penal secara umum dalam tesisnya tidak menjelaskan secara spesifik pada perlindungan hak-hak anak sebagai generasi penerus bangsa, pada penulisan kali ini penulis akan menekankan pada penerapan nilai keadilan kepada anak yang melakukan tindk pidana kekerasan, yang dimana menurut Hari Budiyanto nilai perlindungan dan kesejahteraan anak sebagai generasi bangsa sert pula nilai keadilan khsusunya terhadap anak yang telah melakukan tindak pidana kekerasan berpotensi tidak terwujud.

Selanjutnya Lilik Siyaga dari Universitas Jenderal Soedirman Purwokerto, pada tesis milik Lilik Siyaga menjelaskan dasar memutus perkara pada tindak pidana terhadap nyawa manusia oleh anak yang berdasarkan Undang-Undang. Disini penulis akan menyarankan agar para instansi tekait perlu melakukan sosialisasi kepada Hakim agar harus memperhatikan kepentingan anak, di bidang pendidikan, pembinaan, dan latihan kerja di Lapas Khusus Anak, dengan putusan yang bermanfaat dengan memperhatikan Pasal 64 ayat (2) Undang-Undang Nomor 23 Tahun 2002 tentang Perlindungan Anak.

\section{Permasalahan dan Gap Analisis}

Sehubungan dengan permasalahan dan gap analisis dalam tulisan ilmiah ini, penulis lebih menekankan pada kajian hukum terkait penegakan hukum oleh polisi dalam tindak pidana kekerasan oleh anak yang berbasis keadilan di Kabupaten Siak Indrapura, dibandingkan dengan peneliti sebelumnya yaitu, Lilik Siyaga dan Galih Martino, hanya mengkaji tentang proses penyelesaian tindak pidana kekerasan yang dilakukan oleh pelajar dan upaya penaggulangannya. 


\section{B. Metode Penelitian}

Penelitian ini merupakan pendekatan Socio Legal. Pendekatan socio legal digunakan untuk menganalisis berbagai peraturan perundang-undangan dan hukum terkait penegakan hukum oleh polisi dalam tindak pidana kekerasan oleh anak yang berbasis keadilan di Kabupaten Siak Indrapura. Sementara itu pendekatan penelitian socio legal adalah penelitian yang mengacu kepada norma-norma dan asas-asas hukum yang terdapat dalam peraturan perundang-undangan dan putusan pengadilan/fakta dilapangan. Ronald Dworkin menyebut metode penelitian tersebut juga sebagai penelitian doctrinal (doctrinal research), yaitu suatu penelitian yang menganalisis baik hukum sebagai law as it written in the book, maupun hukum sebagai law as it is decided by the judge through judicial process. (Strauss, dan Corbin, 1979: 7)

Tiga alasan penggunaan penelitian hukum empiris yang bersifat kualitatif. Pertama, analisis kualitatif didasarkan pada paradigma hubungan dinamis antara teori, konsep-konsep dan data yang merupakan umpan balik atau modifikasi yang tetap dari teori dan konsep yang di dasarkan pada yang dikumpulkan. Kedua, data yang akan dianalisis beraneka ragam, memiliki sifat dasar yang berbeda antara yang satu dengan lainnya, serta tidak mudah untuk dikuantifsir. Ketiga, sifat dasar data yang akan dianalisis dalam penelitian adalah bersifat menyeluruh dan merupakan suatu kesatuan yang integral, dimana hal itu menunjukkan adanya keanekaragaman data serta memerlukan informasi yang mendalam (indepth information). (Filstead, $1979: 38$

Ketiga kriteria penelitian kualitatif tersebut terdapat dalam penelitian tesis ini, sehingga sangat beralasan menggunakan metode kualitatif dalam analisis data. Penelitian ini bersifat menyeluruh karena berupaya mendalami keseluruhannya. Penelitian ini juga berupaya mencari hubungan yang harmonis dari konsep-konsep yang ditemukan dalam bahan-bahan hukum primer dan skunder dengan menggunakan teori atau doktrin-doktrin hukum, (Chai Podhisita : 7) terkait penegakan hukum oleh polisi dalam tindak pidana kekerasan oleh anak yang berbasis keadilan di Kabupaten Siak Indrapura.

\section{Hasil Penelitian dan Pembahasan}

\section{Penegakan Hukum Oleh Polisi Dalam Tindak Pidana Kekerasan Anak dan Bagaimana Implikasi Terhadap Perwujudan Keadilan di Kabupaten Siak Indrapura}

Penegakan hukum oleh polisi terhadap anak yang melakukan tindak pidana kekerasan oleh anak tidak boleh sewenang-wenang, karena akan berakibat pada psikologis anak yang masih dapat di bimbing ke arah yang lebih baik serta anak pada umumnya masih mempunyai masa depan yang cerah dan wajib dilindungi haknya oleh Negara. Dalam kenyataannya, isu penegakan hukum yang sewenangwenang oleh badan eksekutif dalam pemerintahaan saat ini terkesan sewenangwenang, termasuk dalam hal ini adalah lembaga Kepolisian khsusunya dalam menangani anak yang melakukan tindak pidana kekerasan. Namun disisi lain Polisi 
secara umum tidak dapat disudutkan/disalahkan secara absolut, karena kesalahan dalam penegakan hukum bersifat relatif, hal ini jika dikaji dari sisi faktor-faktor penegakan hukum dapat disebabkan oleh faktor struktur hukum, substansi hukum dan budaya hukumnya. Sehingga masyrakat sangat berharap penegakan hukum yang berbasis keadilan dapat ditegakkan di negeri ini, selain itu penegak hukum yang menjunjung tinggi nilai keadilan dapat terwujud sebagai langkah kontruktif dalam sistim penegakan hukum yang ada di Indonesia kedepannya. Kondisi ini apabila ditinjau dari teori Bekerjanya Hukum menurut Robert B. Seidman dan William J. Chambliss, maka dapat dilihat pada bagan berikut ini:

\section{Bagan 2}

\section{Teori Bekerjanya Hukum (Sesuai dengan realita di lapangan)}

Birokrasi \& Harapan Masyarakat Terhadap Penegakan Hukum Oleh Polisi Terhadap Anak Yang Berhadapan Dengan Hukum

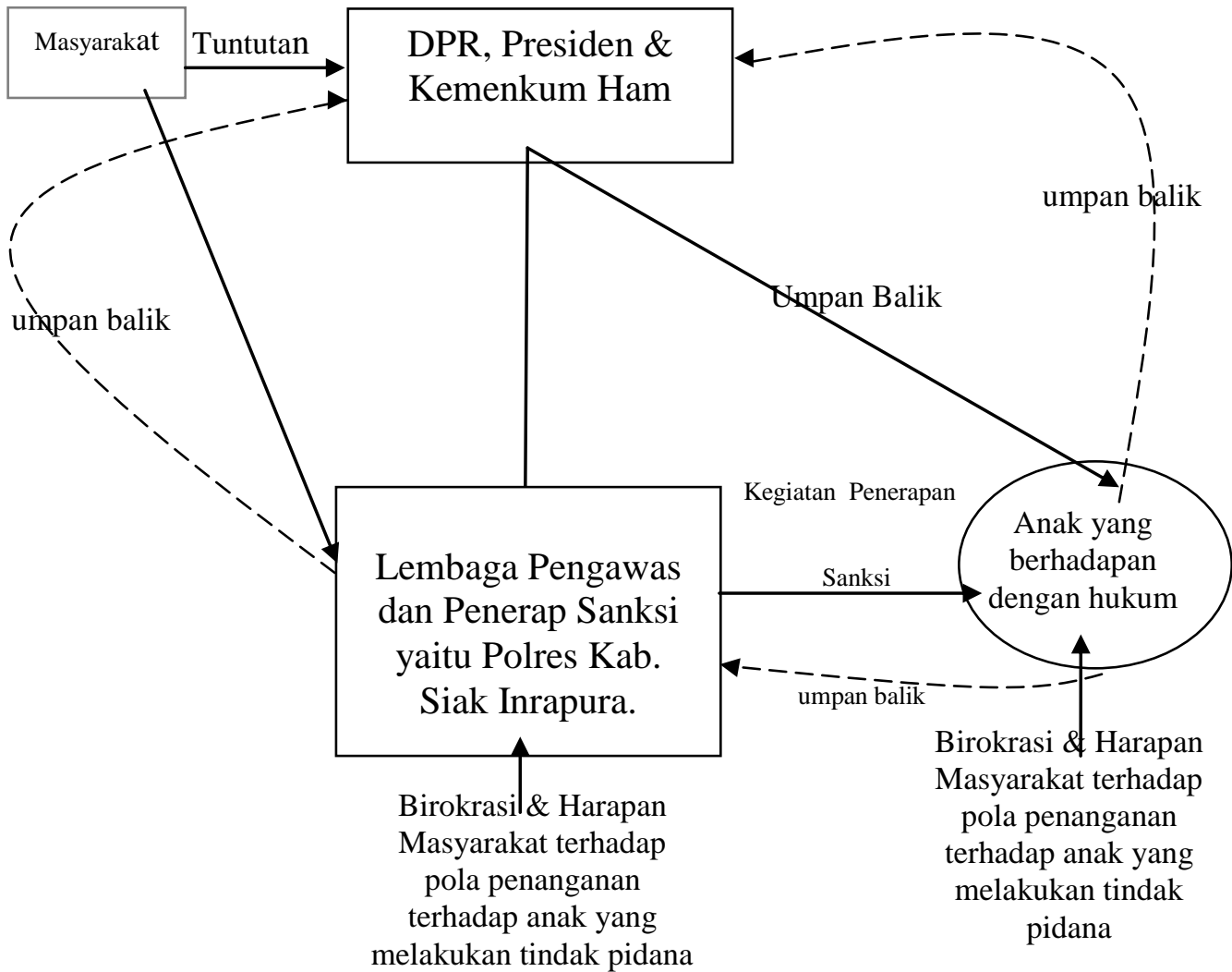


Keterangan Bagan:

Dari bagan tersebut di atas menunjukkan bahwa urgennya penegakan hukum yang dilakukan oleh Polisi di Kabupaten Siak Indrapura harus mengedepankan apa yang menjadi 3 nilai dasar dalam penegakan hukum yaitu berbasis nilai kepastian, kemanfaatan dan keadilan sehingga akan mempengaruhi pandangan masyarakat terhadap eksistensi Lembaga Kepolisian secara umum, serta akan mempertaruhkan nilai kesejahteraan anak dimasa mendatang. Dalam kata lain, apabila Undang-Undang Perlindungan Anak telah mengamantkan kepada petugas penegak hukum dalam hal ini kepolisian yang mempunyai fungsi eksekutif agar melaksanakan kewajibannya dalam melaksanakan penegakan hukum kepada anak pidana yang berhak atas perlindungan hukum serta hak-hak nya sebagai anak bangsa, karena di sisi lain lembaga kepolisian khususnya pada Polres Kabupaten Siak Indrapura dalam pelaksanaannya belum msih belum melindungin apa yang menjadi hak-hak yang telah dijabarkn terebut, sehingga berdampak akibat hukum bagi pihak ketiga. Dampak ini berpengaruh luas bagi masyarakat-masyarakat khususnya orang tua anak tindak pidana kekerasan serta anak-anak yang berhadapan dengan hukum lainnya di berbagai wilayah di Indonesia (khususnya kota-kota besar) sehingga akan menimbulkan image negatif dari masyarakat terhadap kinerja Lembaga Kepolisian yang dianggapnya belum efektif dan optimal.

Dampak buruk lainnya dengan adanya image negatif (merupakan tuntutan dan harapan masyarakat) di kalangan Komisi serta lembaga perlindungan anak berkenaan dengan maraknya tuntutan terhadap Polisi yang dalam eksistensinya telah berperan dalam penegakan hukum kepada anak pidana, tentunya juga berdampak besar bagi lembaga Pembuat Peraturan dan lembaga Penerap Sanksi, sehingga lembaga ini perlu bekerja ekstra untuk melakukan langkah-langkah perbaikan yang konstruktif agar seluruh pihak terkait di lingkungan Lembaga Kepolisian dalam melaksanakan tugas dan kewajibannya, untuk selalu berpedoman pada Undang-Undang Perlindungan Anak dan Undang-Undang POLRI. Pada hakekatnya, maraknya problematika penegakan hukum oleh polisi terhadap anak yang melakukan tindak pidana kekerasan ini dipengaruhi oleh 2 (dua) faktor utama yaitu faktor normatif dan faktor sosiologis, termasuk juga tuntutan / harapan masyarakat.

\section{Penerapan Hukum Pidana Formil Dalam Penanganan Tindak Pidana Dengan Kekerasan yang Dilakukan Oleh Pelajar Sekolah.}

Untuk mengetahui ketentuan peraturan perundang-undangan yang dijadikan pedoman oleh penyidik atau penyidik pembantu dalam melakukan penyidikan terhadap tindak pidana dengan kekerasan yang dilakukan oleh anak pelajar sekolah, dapat dilihat dari tabel sebagai berikut: : 
Tabel 5



Dari data tersebut diatas, dapat dijelaskan bahwa 13 penyidik yang dijadikan sampel maka yang menggunakan KUHP, KUHAP dan Undang- Undang No. 3 Tahun 1997 tentang Pengadilan Anak dalam menyidik tindak pidana dengan kekerasan yang dilakukan oleh pelajar sekolah sebanyak 2 orang atau 15,38\%, yang menggunakan KUHP, KUHAP, JUKLAK atau JUKNIS sebanyak 6 orang atau $46,15 \%$, dan yang berpedoman pada disposisi pimpinan sebanyak 5 orang atau 41,66 $\%$.

\section{a. Penerapan KUHAP}

KUHAP merupakan undang-undang yang berisikan ketentuan- ketentuan tertulis tentang pelaksanaan ketentuan dalam hukum pidana. Pelaksanaan ketentuanketentuan hukum pidana tersebut tentunya akan selalu bersinggungan dengan hakhak seseorang. Dengan demikian harus ada ketentuan yang bersifat limitatif yang mengatur tentang sejauh mana tindakan-tindakan yang boleh dilakukan para pelaksana hukum dalam menjalankan ketentuan hukum pidana yang berlaku. Tujuan yang ingin dicapai dari penerapan KUHAP ini adalah untuk mendapatkan kebenaran yang sesungguhnya terhadap suatu peristiwa tindak pidana atau yang lazim disebut dengan kebenaran materiil, serta untuk mencegah agar pidana tidak dijatuhkan terhadap orang yang tidak bersalah.

Adanya penyidik atau penyidik pembantu yang masih berpedoman pada disposisi pimpinan dalam melakukan penyidikan perkara pidana dengan kekerasan yang dilakukan oleh pelajar yaitu sebanyak 5 orang atau 41,66\%, menunjukan bahwa tingkat profesionalisme penyidik masih rendah sehingga masih sering terjadi pelanggaran terhadap ketentuan KUHAP yang pada akhirnya tujuan diterapkannya 
KUHAP yaitu untuk mendapatkan kebenaran materiil tidak dapat tercapai. Dalam hal pelaksanaan upaya paksa khususnya penangkapan diakui juga oleh Kasubnit IV Iptu Susanto bahwa dalam pelaksanaan penangkapan anak pelajar sekolah pelaku tindak pidana dengan kekerasan masih sering disertai dengan tindakan kekerasan oleh petugas yang bersangkutan secara emosional, antara lain berupa makian disertai pemukulan, dibentak-bentak, tembakan peringatan ke udara terhadap tersangka yang berusaha melarikan diri. (Susanto : 2018).

Sebagaimana disampaikan diatas bahwa tujuan yang ingin dicapai dari penerapan KUHAP ini adalah untuk mendapatkan kebenaran yang sesungguhnya terhadap suatu peristiwa tindak pidana atau yang lazim disebut dengan kebenaran materiil, serta untuk mencegah agar pidana tidak dijatuhkan terhadap orang yang tidak bersalah. Penerapan KUHAP secara benar dan tepat terhadap kasus tindak pidana dengan kekerasan dengan pelaku pelajar seperti dilaksanakannya aturan tata cara tentang penangkapan, dipenuhinya hak-hak tersangka, akan berdampak positif terhadap tujuan yang ingin dicapai oleh hukum itu sendiri. Dengan demikian memidana bukanlah untuk memuaskan tuntutan absolut dari keadilan. Pidana bukanlah sekedar untuk melakukan pembalasan atau pengimbalan kepada orang yang telah melakukan sesuatu tindak pidana, tetapi mempunyai tujuan-tujuan tertentu yang bermanfaat. Jadi dasar pembenaran adanya pidana ini adalah terletak pada tujuannya.

Terjadinya tekanan fisik ataupun psikis yang dilakukan oleh penyidik saat dilakukan upaya paksa maupun saat dilakukan pemeriksaan dalam rangka pembuatan BAP tersangka terhadap pelajar pelaku tindak pidana dengan kekerasan demi untuk mendapatkan pengakuan dari tersangka yang bersangkutan adalah sangat bertentangan dengan tujuan dari KUHAP, lebih jauh lagi tujuan pemidanaan sebagaimana yang diharapkan menjadi tidak tercapai.

\section{b. Penerapan Undang-Undang No. 3 Tahun 1997 tentang Pengadilan Anak.}

Undang-Undang No. 3 Tahun 1997 tentang Pengadilan Anak merupakan hukum khusus (Lex spesialis) dari ketentuan-ketentuan KUHAP dan KUHP. Dalam Undang-Undang ini telah mengatur tersendiri hukum acara pidananya, dan juga mengatur sejumlah sanksi pidana terhadap anak yang terlibat tindak pidana. Dengan lahirnya Undang-Undang Pengadilan Anak ini diharapkan petugas yang menangani perkara anak, dari tingkat penyidikan sampai tingkat pengadilan, semuanya mendalami masalah anak, sebagai pedoman dalam menyelesaikan perkara-perkara yang menyangkut masalah anak, sehingga anak setelah perkaranya diputus, secara pisik dan mental siap menghadapi masa depannya yang lebih baik.

Pertimbangan dibentuknya undang-undang tersebut yaitu : bahwa anak adalah bagian dari generasi muda sebagai salah satu sumber daya manusia yang merupakan potensi dan penerus cita-cita perjuangan bangsa, yang memiliki peranan strategis dan mempunyai ciri dan sifat khusus, memerlukan pembinaan dan perlindungan dalam rangka menjamin pertumbuhan dan perkembangan fisik, mental, dan sosial secara utuh, serasi, selaras, dan seimbang. Bahwa untuk melaksanakan pembinaan dan memberikan perlindungan terhadap anak, diperlukan dukungan, baik yang menyangkut kelembagaan maupun perangkat hukum yang 
lebih mantap dan memadai, oleh karena itu ketentuan mengenai penyelenggaraan pengadilan bagi anak perlu dilakukan secara khusus.

Kesalahan dalam memperlakukan tersangka pelajar oleh penyidik pada saat dilaksanakan penyidikan kasusnya, akan sangat membahayakan perkembangan baik fisik maupun psikisnya pada saat mereka kembali ke masyarakat setelah menjalani hukuman. Hasil pengamatan kegiatan pemeriksaan yang dilakukan oleh penyidik terhadap tersangka pelajar pelaku tindak pidana dengan kekerasan dalam rangka pembuatan Berita Acara Pemeriksaan Tersangka, ditemukan bahwa dalam melakukan pemeriksaan perlakuannya tidak jauh berbeda dengan pemeriksaan terhadap tersangka orang dewasa. Baik yang menyangkut tempat pemeriksaan, waktu pemeriksaan, ataupun pedoman tata cara pemeriksaannya. Penyidik dalam melakukan pemeriksaan terkadang membentak-bentak tersangka, melakukan ancaman dengan kata-kata dan gerakan badan seolah-olah akan dipukul, dan tersangka tidak didampingi penasehat hukum.

Pidana bukanlah sekedar untuk melakukan pembalasan atau pengimbalan kepada orang yang telah melakukan sesuatu tindak pidana, tetapi mempunyai tujuan-tujuan tertentu yang bermanfaat. Jadi dasar pembenaran adalah terletak pada tujuannya. Maka sanksi pidana (sebagai wujud penegakan hukum) yang diberikan kepada pelajar yang melakukan tindak pidana hendaknya bukanlah untuk memuaskan bagi pihak korban akan tetapi untuk mencegah agar mereka tidak mengulangi perbuatannya lagi. Tujuan lebih jauh lagi dari penegakan hukum tadi adalah untuk menciptakan, memelihara serta mempertahankan kedamaian dan kesejahteraan masyarakat.

\section{Faktor Penghambat Dalam Penegakan Hukum Oleh Polisi Dalam Tindak Pidana Kekerasan Oleh Anak Sehingga Perwujudan Keadilan Belum Tercapai Di Kabupaten Siak Indrapura}

Untuk mengetahui hambatan-hambatan yang ada, di sini Penulis menggunakan indikator uji dengan beberapa faktor yang mempengaruhi penegakan hukum di Polres Kabupaten Siak Indrapura. Tingkat keberhasilan penegakan hukum dapat dianalisis berdasarkan faktor tersebut, adapun faktor tersebut antara lain :

\section{Penegak Hukum}

Bahwa program kerja Polda telah dijadikan sebagai acuan untuk melaksanakan tugas-tugas utama Sat Serse dan dijabarkan menjadi program kegiatannya. Penulis dapat menganalisa bahwa mengingat luasnya ruang lingkup tugas serse yang harus dikerjakan, maka untuk mempermudah pemahaman dan pelaksanaan tugas oleh anggota pada fungsi Serse, disusun suatu batasan-batasan tugas yang jelas dan terarah dalam bentuk tugas pokok Serse. Dengan dibuatnya ketentuan tugas pokok Serse tersebut diharapkan kebijakan-kebijakan yang telah digariskan oleh pimpinan tingkat atas dalam bentuk program kerja, dapat dilaksanakan oleh satuan-satuan yang berada ditingkat bawah, dalam hal ini oleh Sat Serse Polres Kabupaten Siak Indrapura. Hal yang utama adalah apakah petugas pada fungsi tersebut benar-benar tahu dan mengerti akan tugas dan tanggung jawabnya. 
Terhadap struktur organisasi Sat Serse Polres Kabupaten Siak Indrapura adalah struktur tersebut sudah mengacu kepada ketentuan yang telah ditetapkan oleh orgnisasi Polri sesuai dengan Surat Keputusan Kapolri No.Pol: Skep/07/VII/1985 tanggal 1 Juli 1985 tentang Pokok-Pokok Organisasi dan Prosedur Serta Daftar Susunan Personil. Permasalahan penyidikan tindak pidana dengan kekerasan yang dilakukan oleh pelajar sekolah, dilaksanakan oleh unit-unit tertentu sesuai dengan jenis tindak pidananya dan pembagian tugas terhadap masing-masing unit tersebut, seperti unit Jatanras disamping menangani tindak pidana dengan kekerasan yang dilakukan oleh orang dewasa, juga menangani tindak pidana dengan kekerasan yang dilakukan oleh pelajar sekolah. Hal-hal yang menjadi perhatian Penulis terhadap struktur tersebut adalah bahwa tidak ada unit yang secara khusus menangani tindak pidana yang dilakukan oleh pelajar sekolah. Akibatnya penanganan tindak pidana dengan kekerasan yang pelakunya tergolong pelajar sekolah yang masih anak-anak perlakuannya dapat dikatakan hampir tidak ada bedanya dengan penanganan perkara yang pelakunya orang dewasa. Penanganan perkara dengan pelaku pelajar yang tidak dibedakan dengan perkara orang dewasa adalah tidak tepat karena sistem yang demikian ini sudah jelas akan merugikan kepentingan pelajar yang bersangkutan. Dengan keadaan tersebut menjadikan penanganan kasus tindak pidana dengan kekerasan yang dilakukan oleh anak pelajar sekolah tidak dapat mencapai hasil yang optimal. Ini menunjukan bahwa kebijakan dari pimpinan terhadap masalah tindak pidana yang dilakukan oleh pelajar yang masih tergolong anak-anak belum mendapatkan atensi secara khusus dalam hal penanganannya. Keadaan yang seperti inilah yang akhirnya justru menjadikan pelajar setelah selesai menjalani proses hukum bukannya insaf akan perbuatannya yang salah tetapi sebaliknya menjadi bertambah pandai untuk melakukan kejahatan. Sehingga tindak pidana dengan kekerasan yang dilakukan oleh pelajar di wilayah hukum Polres Kabupaten Siak Indrapura dari tahun ketahun cenderung mengalami peningkatan.

Jumlah kasus tindak pidana dengan kekerasan yang dilakukan oleh anak pada tahun 2015 terjadi sebanyak 15 kasus dan yang paling sering terjadi adalah jenis tindak pidana kekersan pada pencurian motor sebanyak 7 kali kejadian atau 68 $\%$ dari seluruh tindak pidana dengan kekerasan yang dilakukan oleh anak pada tahun 2015. Kemudian pada tahun 2016 jumlah tindak pidana dengan kekerasan yang dilakukan oleh anak mengalami peningkatan yaitu terjadi sebanyak 22 kasus atau meningkat 7 kasus dibanding tahun sebelumnya, dan jenis kejahatan yang paling banyak terjadi adalah pencurian yaitu sebanyak 3 kasus dari 6 kasus tindak pidana dengan kekerasan yang dilakukan oleh pelajar sekolah yang terjadi pada tahun 2016. Sedangkan pada tahun 2017 jumlah tindak pidana dengan kekerasan yang dilakukan oleh anak tidak mengalami perubahan yaitu tetap 22 kasus. Yang menarik adalah bahwa jenis kejahatan yang mengalami kenaikan secara terus menerus dari tahun 2015 sampai deangan tahun 2017 adalah jenis tindak pidana pencurian motor dengan kekerasan, dimana pada tahun 2015 terjadi 7 kasus kemudian tahun 2016 menjadi 9 kasus dan pada tahun 2017 menjadi 10 kasus. Oleh karena itu perlu dipertimbangkan untuk membentuk satu unit khusus yang mernangani perkara dengan pelaku pelajar sekolah, sehingga pelaksanaan Undang-Undang No. 3 Tahun 1997 Tentang Pengadilan Anak dapat benar-benar dijalankan secara maksimal. Dari lampiran data mengenai jumlah personil Reserse Polres Kabupaten Siak Indrapura 
menurut golongan, DSPP, dan realisasi, menunjukkan bahwa kekurangan personil yang cukup signifikan masih dialami oleh Satuan Reserse Polres Kabupaten Siak Indrapura bila dibandingkan dengan DSPP yang berlaku dilingkungan organisasi Polri, yang antara lain untuk golongan perwira menengah sampai saat ini untuk jabatan kepala satuan reserse masih dijabat oleh personil Polri dengan pangkat Komisaris Polisi yang merupakan golongan perwira menengah. Sedangkan untuk golongan perwira pertama mengalami kekurangan sebesar $15 \%$ yang merupakan tulang punggung dalam melakukan tindakan hukum terhadap kasus-kasus tindak pidana yang terjadi khususnya tindak pidana dengan kekerasan yang dilakukan oleh pelajar sekolah. (Kutipan wawancara penulis dengan Widhiastuti selaku Kaur Bin Ops Polres Kabupaten Siak Indrapura, Polres Kabupaten Siak Indrapura, pada tanggal 2 Februari 2018).

Kekurangan personil tersebut akan sangat berpengaruh terhadap pembagian tugas dan penyelesaian perkara tindak pidana dengan kekerasan yang dilakukan oleh pelajar sekolah pada Sat Serse Polres Kabupaten Siak Indrapura. Untuk mendapatkan tambahan personil penyidik atau penyidik pembantu tentu akan menemui suatu hambatan, untuk itu perlu dipertimbangkan dari segi kualitas anggota yang ada, guna dilakukan pembinaan yang lebih baik. Kualitas dalam hal ini meliputi latar belakang pendidikan yang mencakup pendidikan formal dan pendidikan spesialisasi fungsi kepolisian dan lamanya pengalaman kerja dibidang tersebut.

Sedangkan latar belakang pendidikan formalnya dapat dilihat pada uraian sebagai berikut: Berdasarkan lampiran data mengenai tingkat pendidikan personil dapat dijelaskan bahwa dari 148 orang personil Sat Serse Polres Kabupaten Siak Indrapura maka dijumpai sebanyak 15 (lima belas) orang atau 10,14\% yang berpendidikan setingkat Perguruan Tinggi, berpendidikan setingkat SLTA sebanyak 129 orang atau $87,16 \%$ yang sebagian besar merupakan personil dari golongan bintara yaitu 119 orang, 4 orang atau 2,70 \% berpendidikan setingkat SLTP. Latar belakang pendidikan formal ini sangat berpengaruh terhadap kemampuan penyidik atau penyidik pembantu dalam memahami dan menguasai materi yang terkandung dalam KUHAP maupun Undang-Undang No. 3 Tahun 1997 tentang Pengadilan Anak yang pada akhirnya akan berpengaruh terhadap keberhasilan penyidikan tindak pidana dengan kekerasan dengan pelaku pelajar. ( Kutipan wawancara penulis dengan Widhiastuti selaku Kaur Bin Ops Polres Kabupaten Siak Indrapura, Polres Kabupaten Siak Indrapura, pada tanggal 2 Februari 2018).

\section{Sarana dan Prasarana}

Mengingat sarana dan prasarana ini sangat penting didalam menunjang keberhasilan tugas represif dalam penanggulangan tindak pidana dengan kekerasan yang dilakukan oleh pelajar sekolah ditambah lagi dengan tantangan tugas yang semakin berat yang harus dihadapi oleh personil pada satuan tersebut, maka terhadap sarana dan prasarana yang mendukung kelancaran tugas perlu disediakan secara baik dan lancar. Berdasarkan lampiran data mengenai sarana dan prasarana, dapat dijelaskan bahwa dalam melakukan penyidikan terhadap tindak pidana dengan kekerasan yang dilakukan oleh pelajar sekolah, penyidik atau penyidik pembantu yang bersangkutan masih harus menyediakan sarana atau prasarana yang berupa alat 
tulis kantor secara swadaya karena alat-alat jenis tersebut tidak dianggarkan oleh dinas. Sedangkan dari 28 buah komputer yang ada ternyata 3 buah komputer atau $10,71 \%$ mengalami rusak ringan dan tidak dapat dipergunakan. Keterbatasan sarana dan prasarana tersebut sangat mempengaruhi produktivitas dan kinerja penyidik pada satuan Serse tersebut dalam menangani tindak pidana dengan kekerasan dengan pelaku anak pelajar sekolah.

\section{Tindakan upaya paksa dalam penyidikan tindak pidana dengan kekerasan yang dilakukan oleh anak pelajar sekolah.}

a. Penangkapan

Pasal 43 ayat 1 Undang-Undang Nomor 3 Tahun 1997 Tentang Pengadilan Anak berbunyi "Penangkapan Anak Nakal dilakukan sesuai dengan ketentuan Kitab Undang-Undang Hukum Acara Pidana." Berdasarkan hasil wawancara seperti yang diuraikan pada bab ini dalam hal penangkapan, dapat dijelaskan bahwa untuk pelaksanaan penangkapan terhadap pelajar pelaku tindak pidana dengan kekerasan secara administrasi sudah sesuai dengan ketentuan yang ada didalam KUHAP. Berdasarkan hasil wawancara dengan Kaur Bin Ops AKP Widhastuti maupun Aiptu Susanto, saat pelaksanaan penangkapan tindakan kekerasan masih sering dilakukan oleh petugas terhadap pelajar pelaku tindak pidana dengan kekerasan.

Adanya perlakuan kekerasan tersebut jelas telah melanggar butir ke 13 Keppres No. 36 Tahun 1990 Tentang Pengesahan Konvensi tentang Hak-hak Anak yang menyatakan bahwa hak-hak anak "Memperoleh perlindungan akibat kekerasan fisik, mental, penyalahgunaan, penelantaran atau perlakuan salah (eksploitasi) sertas penyalahgunaan seksual". Disamping itu adanya perlakuan tersebut menunjukan bahwa perlakuan terhadap pelajar pelaku tindak pidana dengan kekerasan tidak ada bedanya dengan perlakuan terhadap pelaku tindak pidana dengan tersangka orang dewasa, hal ini akan sangat merugikan kepentingan pelajar yang bersangkutan mengingat mereka merupakan generasi muda yang perkembangan sosialnya masih perlu pembinaan.

\section{b. Penahanan}

Menjadi perhatian penulis adalah masalah penempatan tahanan pelajar pelaku tindak pidana dengan kekerasan yang belum sesuai dengan ketentuan Pasal 45 ayat (3) Undang-Undang Nomor 3 Tahun 1997 Tentang Pengadilan Anak yang berbunyi "Tempat tahanan anak harus dipisahkan dari tempat tahanan orang dewasa". Karena berdasarkan hasil pengamatan dan wawancara dengan penyidik Sat Serse Polres Kabupaten Siak Indrapura menyatakan bahwa penempatan pelajar pelaku tindak pidana dengan kekerasan saat dilakukan proses penyidikan oleh Polri, adalah digabungkan dengan para pelaku tindak pidana orang dewasa. Sehingga secara psikologis akan sangat berpengaruh terhadap perkembangan jiwa pelajar yang bersangkutan terutama setelah selesai menjalani putusan sidang tersebut. 


\section{Kontruksi Penegakan Hukum Oleh Polisi Terhadap Tindak Pidana Kekerasan Oleh Anak Sehingga Perwujudan Keadilan Dapat Tercapai di Kabupaten Siak Indrapura}

Kepolisian merupakan lembaga sub sistem dalam SPP yang mempunyai kedudukan pertama dan utama. Kedudukan yang demikian oleh Har- kristuti Harkrisnowo dikatakan sebagai the gate keeper of the criminal justice system. Tugas polisi dalam rangkaian SPP adalah melakukan penyidikan yang berujung pada dihasilkannya Berita Acara Pemeriksaan (BAP). Dalam penyidikan ini polisi sering melakukan kekerasan pada tersangka. Penggunaan kekerasan oleh polisi merupakan salah satu aspek dari paradigma ganda polisi, yaitu sebagai the strong hand of society dan the soft hand of society. Konsep tentang kekerasan sebagaimana di introdusir oleh Kiefer, mengacu kepada dua hal. Pertama, menunjuk kepada suatu tindakan untuk menyakiti orang lain, sehingga menyebabkan luka-luka atau mengalami kesakitan. Kedua, menunjuk kepada penggunaan kekuatan fisik yang tidak lazim dalam suatu kebudayaan. ( Barda Nawawi Arief, 1998 : 20) Kekerasan dalam pengertian yang luas tidak hanya meliputi dimensinya yang bersifat fisik, akan tetapi juga dimensi yang bersifat psikologis. Dalam hubungan antara kekerasan personal dan kekerasan struktural, Nasikun dengan mengikuti konsep Galtung, menyatakan bahwa kendati kedua bentuk kekerasan itu secara empiris dapat berdiri sendiri-sendiri tanpa mengandaikan satu sama lain, tumbuh melalui pengalaman historis sosiologis yang panjang. Keduanya secara empiris mempunyai hubungan dialektis. Mereka yang memperoleh keuntungan dari penggunaan kekuasaan struktural (terutama yang berada pada puncak struktur kekuasaan) pada umumnya akab berusaha mempertahankan kekuasaannya (status quo) melalui kekerasan struktural yang dilakukan secara tersembunyi (untuk menjaga citra kekuasaanya) melalui penggunaan instrumen kekuasaan yang dimilikinya seperti kepolisian, tentara dan hukum. (Nasikun, $1996: 4-6$ )

Penyimpangan perilaku polisi terhadap pelaku tindak pidana kekerasan yang dilakukan oleh anak merupakan gambaran umum tentang kegiatan petugas polisi yang tidak sesuai dengan wewenang resmi petugas, wewenang organisasi, nilai dan standar perilaku sopan serta dapat menjauh yang menjadi nilai dasar dalam menegakkan hukum yaitu nilai keadilan. Pencapaian suatu keadilan, pada abad modern salah seorang yang di anggap memiliki peran penting dalam mengembangkan konsep keadilan adalah John Borden Rawls. Rawls berpendapat bahwa keadilan hanya dapat ditegakkan apabila negara melaksanakan asas keadilan, berupa setiap orang hendaknya memiliki hak yang sama untuk mendapatkan kebebasan dasar (basic liberties); dan perbedaan sosial dan ekonomi hendaknya distur sedemikian rupa sehingga memberi manfaat yang besar bagi mereka yang berkedudukan paling tidak beruntung, dan bertalian dengan jabatan serta kedudukan yang terbuka bagi semua orang berdasarkan persamaan kesempatan yang layak. John Rawls memunculkan suatu ide dalam bukunya A Theory of Justice atau teori keadilan yang bertujuan agar dapat menjadi alternatif bagi doktrin-doktrin yang mendominasi tradisi filsafat terdahulunya, dengan cara menyajikan konsep keadilan yang mengeneralisasikan dan mengangkat teori kontrak sosial yang diungkap oleh, 
katakanlah, Locke, Rousseau dan Kant ke tingkat yang lebih tinggi. Oleh Rawls cara pandang keadilan ini disebut keadilan sebagai fairness.

Sehubungan dengan kontruksi yang mengedepankan nilai keadilan terhadap kepentingan terbaik anak selaku pelaku tindak pidana kekerasan, ide yang paling relevan untuk dipakai dalam penelitian ini adalah gagasan tentang suatu objek atau fenomena tertentu yang bersifat mendasar, yang dijadikan patokan atau sudut pandang. Ide dasar merupakan pandangan dunia (weltblit) yang diyakini dan menentukan cara pandang terhadap suatu fenomena. Ia berfungsi sebagai the central cognitive resource (pusat sumber pengamatan) yang menentukan rasionalitas suatu fenomena, baik tentang apa yang menjadi pokok persoalan maupun cara melihat dan menjelaskan fenomena itu. Sebagai gagasan yang bersifat mendasar, maka ide dasar lebih menyerupai cita, yakni gagasan dasar mengenai suatu hal. Misalnya cita hukum atau rechtsidee, merupakan konstruksi piker (ide) yang mengarahkan hukum kepada cita-cita yang diinginkan. Seperti yang dikatakan Rudolf Stamler, cita hukum merupakan leitstern (bintang pemandu) bagi tercapainya cita-cita masyarakat. (Attamimi, 1990 : 308) Karena itu, cita hukum akan mempengaruhi dan berfungsi sebagai asas umum yang mempedomani (guiding principle), norma kritik (kaidah evaluasi) dan factor yang memotivasi dalam penyelenggaraan hukum (pembentukan, penemuan, penerapan hukum) dan perilaku hukum. Jadi, dirumuskan dan dipahaminya cita hukum akan memudahkan penjabarannya ke dalam berbagai perangkat aturan kewenangan dan aturan perilaku serta memudahkan terjaganya konsistensi dalam penyelenggaran hukum. (Sidharta, 1999 : 181). Dengan demikian, sebuah ide dasar selalu bersifat konstitutif, artinya, ide dasar itulah yang menentukan masalah, metode, dan penjelasan yang dianggap relevan untuk ditelaah, atau mengikuti alur pikir Gustav Radbruch mengenai rechtsidee yang menurutnya berfungsi sebagai dasar yang bersifat konsitutif bagi hukum positif. Sistem Peradilan Pidana Anak (Juvenile Justice System) adalah segala unsur sistem peradilan pidana yang terkait di dalam penanganan kasus-kasus kenakalan anak. Pertama, polisi sebagai institusi formal ketika anak nakal pertama kali bersentuhan dengan sistem peradilan, yang juga akan menentukan apakah anak akan dibebaskan atau diproses lebih lanjut. Kedua, jaksa dan lembaga pembebasan bersyarat yang juga akan menentukan apakah anak akan dibebaskan atau diproses ke pengadilan anak. Ketiga, Pengadilan Anak, tahapan ketika anak akan ditempatkan dalam pilihan-pilihan, mulai dari dibebaskan sampai dimasukkan dalam institusi penghukuman. Yang terakhir, institusi penghukuman. (Supatmi dan Tunduk, 2003 : 2). Institusi kepolisian merupakan institusi negara yang pertama kali melakukan intervensi terhadap anak yang berkonflik dengan hukum. Penangkapan, penahan, penyelidikan, dan penyidikan merupakan kewenangan kepolisian untuk menegakkan sistem peradilan pidana anak. Dalam menjalankan tugasnya kepolisian diberikan kewenangan diskresi (discretionary power). Kewenangan diskresi adalah kewenangan legal di mana kepolisian berhak untuk meneruskan atau tidak meneruskan suatu perkara. Berdasarkan kewenangan ini pula kepolisian dapat mengalihkan (diversion) terhadap suatu perkara anak sehingga anak tidak perlu berhadapan dengan penyelesaian pengadilan pidana secara formal.

Susanti menyatakan bahwa pada dasarnya kasus yang dilaporkan ke Polres Kabupaten Siak Indrapura tidak semua berkasnya dilimpahkan ke Kejaksaan. Ketika 
penyidikan dilakukan, terkadang antara pihak korban dan pelaku melakukan perdamaian, biasanya perdamaian ini terjadi karena bantuan pihak ketiga seperti tokoh adat atau tokoh masyarakat. Perdamaian itu biasanya disertai ganti rugi yang ditandai dengan kesepakatan antara korban dan pelaku. Terkadang pihak kepolisian dilibatkan dan tidak dilibatkan namun apabila perkara tersebut sudah diselesaikan secara damai biasanya pihak korban, pelaku dan tokoh masyarakat atau pihak-pihak yang terlibat datang melapor ke Polres Kabupaten Siak Indrapura. Namun apabila kasus pencabulan dimana korban atau orang tua korban tidak bersediamelakukan perdamaian dengan adanya surat pernyataan yang ditandatangani oleh orang tua korban maka kasus ini akan diteruskan ke kejaksaan. (Kutipan wawancara penulisa dengan Susanti selaku Kepala Unit Perlindungan Perempuan dan Anak Satuan Reserse Kriminal Polres Kabupaten Siak Indrapura, Polres Kabupaten Siak Indrapura, pada tanggal 6 Februari 2018).

Pada tahap ini kewenangan polisi dalam mengalihkan (diversi) perkara anak demi keadilan restributif telah terjadi dimana terjadi penciutan kasus pada tahun 2017 dari 31 kasus menjadi 25 kasus. Berarti ada 6 kasus yang mengalami diversi. Berdasarkan 25 kasus yang diteruskan ke kejaksaan dapat dikatakan kewenangan diskresi belum dipergunakan secara maksimal untuk menangani perkara anak. Fakta ini menunjukkan kepolisian belum menggunakan kewenangan diskresinya dalam menangani perkara anak. (Kutipan wawancara penulis dengan Susanti selaku Kepala Unit Perlindungan Perempuan dan Anak Satuan Reserse Kriminal Polres Kabupaten Siak Indrapura, Polres Kabupaten Siak Indrapura, pada tanggal 6 Februari 2018).

Alasan pihak kepolisian tidak menggunakan kewenangan diskresi mereka secara maksimal dikarenakan ada beberapa kasus anak yang wajib mereka teruskan ke kejaksaan seperti kasus pencabulan (pemerkosaan) dan narkoba. Sedangkan untuk kasus tindak pidana ringan seperti kasus pencabulan biasa, penganiayaan atau pencurian biasanya dilakukan diversi. Sebagaimana dikemukakan oleh Susanti bahwa: (Kutipan wawancara penulisa dengan Susanti selaku Kepala Unit Perlindungan Perempuan dan Anak Satuan Reserse Kriminal Polres Kabupaten Siak Indrapura, Polres Kabupaten Siak Indrapura, pada tanggal 6 Februari 2018).

Untuk diversi biasanya dilakukan pada kasus tindak pidana ringan atau kasus penganiayaan atau pencurian. Namun untuk kasus pencabulan atau narkoba semua dilimpahkan. Namun biasanya yang pelakunya anak harus diupayakan perdamaian. Perdamaian biasanya disarankan oleh penyidik, digelar dulu dengan pakar hukum di Polres Kabupaten Siak Indrapura dan keputusannya diambil dalam sidang rapat dan biasanya tidak ada tenggang waktu berapa lama untuk proses perdamaian.

Pendapat Susanti ini diperkuat dengan membaca UU No. 2 Tahun 2002 tentang Kepolisian Negara RI, dalam konteks penanganan perkara anak, tidak ada pasal-pasal yang secara khusus mengatur kewenangan diskresi. Bahkan dalam undang-undang ini tidak ada ketentuan yang secara khusus mengatur tindakan dan metode untuk menangani anak yang melanggar hukum pidana. Pasal 16 ayat (1) menetapkan bahwa dalam rangka menyelenggarakan tugas dalam bidang proses pidana, Kepolisian Negara Republik Indonesia berwenang untuk : a. melakukan penangkapan, penahanan, penggeledahan; ... h. mengadakan penghentian penyidikan. Selanjutnya Pasal 18 ayat (1) menyatakan bahwa untuk kepentingan umum pejabat Kepolisian Negara Republik Indonesia dalam melaksanakan tugas 
dan wewenangnya dapat bertindak menurut penilaiannya sendiri. Ketentuan tersebut dapat menjadi acuan bagi polisi untuk mengambil tindakan diskresi, namun penggunaan kewenangan ini belum jelas ditujukan dalam menangani perkara apa.

Beijing Rules mengatur kewenangan diskresi melalui mekanisme pengalihan. Butir 11.1 menyatakan pertimbangan akan diberikan, bilamana layak, untuk menangani pelanggar-pelanggar hukum berusia muda tanpa menggunakan pengadilan formal oleh pihak berwenang yang berkompeten. Selanjutnya Butir 11.2 menetapkan polisi, penuntut umum atau badan-badan lain yang menangani perkaraperkara anak akan diberi kuasa untuk memutuskan perkara-perkara demikian, menurut kebijaksanaan mereka, tanpa menggunakan pemeriksaan-pemeriksaan awal yang formal, sesuai dengan kriteria yang ditentukan untuk tujuan itu di dalam sistem hukum masing-masing dan juga sesuai dengan prinsip-prinsip yang terkandung di dalam peraturan-peraturan ini. Langkah ini diperlukan karena menurut Butir 13.1 dinyatakan bahwa penahanan sebelum pengadilan hanya akan digunakan sebagai pilihan langkah terakhir. Dan menurut Butir 13.2 dinyatakan di mana mungkin, penahanan sebelum pengadilan akan diganti dengan langkah- langkah alternatif, seperti pengawasan secara dekat, perawatan intensif atau penempatan pada sebuah keluarga atau pada suatu tempat atau rumah pendidikan.

Ketentuan ini dititahkan oleh Konvensi Hak Anak Pasal 37 huruf b yang mewajibkan negara untuk menjamin tidak seorang anak pun dapat dirampas kebebasannya secara melanggar hukum atau dengan sewenang-wenang. Penangkapan, penahanan atau pemenjaraan seorang anak harus sesuai dengan undang-undang, dan harus digunakan hanya sebagai upaya jalan lain terakhir dan untuk jangka waktu terpendek yang tepat. Konstruksi hukum serupa dapat ditemukan pada Kovenan Hak Sipil dan Politik Pasal 14 ayat (4) yang menyatakan dalam kasus orang di bawah umur, prosedur yang dipakai harus mempertimbangkan usia mereka dan keinginan untuk meningkatkan rehabilitasi bagi mereka. Berdasarkan ketentuan tersebut, kepolisian mempunyai kewenangan dan kebijakan tersendiri dalam menentukan apakah kasus anak tersebut dapat diselesaikan melalui pengalihan atau tidak seperti kasus pencabulan dan narkoba yang biasanya diteruskan ke penuntutan. Apabila diversi berhasil dilakukan maka akan dilakukan pemulihan. Namun jika diversi tidak berhasil atau kepolisian berdasarkan kewenangannya menyatakan bahwa kasus tersebut harus diterukan maka proses akan dilanjutkan dengan pelimpahan berkas ke kejaksaan. Namun terkadang dalam melaksanakan tugasnya, kepolisian bahkan tidak menawarkan diversi dan restorative justice. Selain itu pihak keluarga korban juga tidak bersedia melakukan perdamaian yang ditandai dengan adanya surat pernyataan diatas materai yang meminta pelaku dihukum seberat-beratnya. Berdasarkan temuan di lapangan, tidak dilakukannya diversi dan restorative justice secara maksimal oleh kepolisian di Polres Kabupaten Siak Indrapura dikarenakan kemampuan pihak polisi sendiri dalam memahami konsep ini masih kurang sehingga dalam penerapannya jarang dilakukan kecuali pihak keluarga korban atau keluarga pelaku yang melakukan perdamaian diluar kepolisian. 


\section{Simpulan}

1. Penegakan hukum oleh polisi dalam tindak pidana kekerasan anak dan bagaimana implikasi terhadap perwujudan keadilan di Kabupaten Siak Indrapura adalah masih menggunakan kekerasan untuk mendapatkan pengakuan atau keterangan dari anak pelaku tindak pidana kekersan dalam penyidikan. Bentuk kekerasan yang dilakukan oleh penyidik adala kekerasan fisik, psikis, maupun hukum. Negara telah gagal memberi perlindungan hukum kepada anak sebagai tersangka yang disebabkan oleh tidak selarasnya peraturan dan realita dilapangan terhadap anak untuk memperjuangkan hak-haknya sebagai pelaku tindak pidana kekerasan. Selain itu kinerja lembaga pengawas dalam penyidikan tidak bekerja secara optimal, dan adanya perlindungan dari institusi kepolisian terhadap penyidik yang melakukan kekerasan terhadap anak pelaku tindak pidana kekerasan sehingga tidak terwujudnya nilai keadilan bagi anak.

2. Faktor penghambat dalam penegakan hukum oleh polisi dalam tindak pidana kekerasan oleh anak sehingga perwujudan keadilan belum tercapai di Kabupaten Siak Indrapura dikarenakan kurangnya pendanaan untuk mendukung pelaksanaan atau kegiatan yang mendukung pengembangan Kota Layak Anak (KLA) di Kabupaten Siak Indrapura, selain itu lambannya pencatatan kasus kekerasan yang terjadi pada anak dikarenakan minimnya tenaga kerja (Sumber Daya Manusia). Dan kurangnya optimalnya peran lembaga yang mengurusi masalah perlindungan anak terlihat dari beberapa kasus dimana para korban melaporkan kasusnya tidak fokus pada satu lembaga saja. Selain itu kurangnya partisipasi masyarakat disebabkan menjaga nama baik dari korban. Korban kekerasan seksual utamanya, banyak yang dikucilkan dan bahkan diusir oleh lingkungannya karena dianggap mengotori dan membawa kesialan bagi lingkungan tersebut. Lingkungan yang tidak memahami masalah dengan baik dapat membuat korban merasa tidak nyaman kembali kelingkungannya.

3. Kontruksi penegakan hukum oleh polisi terhadap tindak pidana kekerasan oleh anak sehingga perwujudan keadilan dapat tercapai di Kabupaten Siak Indrapura adalah dengan membangun atau menciptakan polisi yang profesional harus dimulai dari awal, yaitu pada taraf seleksi dan pendidikan, bahkan upaya ini mesti harus terus dipupuk karena pelaksanaan tugas-tugas kepolisian memiliki standar keahlian dan standar etika yang tinggi, sehingga dapat tercapai penegakan hukum yang kontruktif dalam penegakan hukum terhadap anak pelaku tindak pidana kekerasan. 


\section{Daftar Pustaka}

\section{A. Buku-Buku}

Al-Iman Abu Nashr Muhammad, Membongkar Dosa-dosa Pemilu, (Jakarta: Prisma Media, 2004)

Asas Yuridiksi Ekstrateritorial dalam Undang-Undang Perseroan Terbatas (PT), http://ppatonline.wordpress.com/page/5/, diakses pada tanggal 22 Juli 2017.

Ashshofa Burhan, Metode Penelitian Hukum, (Jakarta: Rineka Cipta, 2010)

Fakhrul, Huda, Penerapan Pemungutan Suara Secara Elektronik Dalam Pemilu di Indonesia, (Jember: Universitas Jember Press, 2013)

HAW Widjaja, Otonomi Desa, (Jakarta: Raja Grafindo Persada, 2003)

Meliza, T. M Silalahi, Penggunaan Kriptografi Pada Elektronik Voting, (Bandung: ITB Press, 2010)

Miriam, Budiharjo, Dasar Dasar Ilmu Politik, (Jakarta: PT Gramedia, 1994)

Muhammad, Shalahudin, Pembuatan Model Elektronik Voting Berbasis Web, (Bandung: ITB Press, 2009) 
